\title{
ANTIMICROBIAL ACTIVITY OF Phoenix dactylifera (DATE PALM) ON SOME SELECTED MEMBERS OF ENTEROBACTERIACEAE
}

\author{
${ }^{1 *}$ Sani, N.M. and ${ }^{1}$ Abdulkadir, F. and ${ }^{2}$ Mujahid, N.S. \\ ${ }^{1,2}$ Department of Microbiology and Biotechnology Federal University Dutse, Jigawa State Nigeria. \\ *Correspondence author: nuramuhammadsani@gmail.com
}

\section{ABSTRACT}

The use of medicinal plants in Africa for therapeutic purpose has been quite a common practice. However, most of these plants are used indiscriminately without proper knowledge of their chemical constituents, spectrum of activity, inhibitory or bactericidal concentrations. Moreover, the widespread and often indiscriminate use of antimicrobial drugs has resulted in resistance of microbes to specific antibiotic treatments. In view of this, the antibacterial activity of Phoenix dactylifera was determined using agar well diffusion method. A total of $2.43 \mathrm{~g}$ and $2.12 \mathrm{~g}$ of the methanolic extract from the original weight of $25 \mathrm{~g}$ was recovered from the leaf and fruit of Phoenix dactylifera respectively. The leaf extracts showed greater antibacterial effects against Klebsiella pneumoniae with zones of inhibition measuring $34 \mathrm{~mm}$, $28 \mathrm{~mm}, 26 \mathrm{~mm}$ and $24 \mathrm{~mm}$ at the concentrations of $40 \mathrm{mg} / \mathrm{ml}, 30 \mathrm{mg} / \mathrm{ml}, 20 \mathrm{mg} / \mathrm{ml}$ and $10 \mathrm{mg} / \mathrm{ml}$ while Salmonella typhi had zones of $20 \mathrm{~mm}$ and $14 \mathrm{~mm}$ at $40 \mathrm{mg} / \mathrm{ml}$ and $30 \mathrm{mg} / \mathrm{ml}$. However, the fruit extract inhibited the growth of all the test organisms at varying concentrations with the highest zone recorded against Salmonella typhi $(38 \mathrm{~mm})$ at $40 \mathrm{mg} / \mathrm{ml}$. The minimum inhibitory concentration (MIC) and minimum bactericidal concentration (MBC) analysis also confirmed the antibacterial effect of these extracts. Phytochemical analysis also showed the presence of Saponins, Tannins, Alkaloids, Steroids, Phenols and Flavonoids. The findings of this research suggest that infection by members of Enterobacteriaceae can be treated using Phoenix dactylifera fruit and leaves as an alternative to conventional antibiotics.

Key Words: Date Palm, Enterobacteriaceae, Salmonella, Phytochemical

\section{INTRODUCTION}

The use and search for medicines and food supplements derived from plants have accelerated in recent years. Ethno pharmacologists, botanists, microbiologists, and natural-products chemists are exploring the Earth for phytochemicals "hints" which could be developed for treatment of infectious diseases (Cowan, 1999). The frequency of lifethreatening infections caused by pathogenic microorganisms has increased worldwide and is becoming an important cause of morbidity and mortality especially in developing countries with lower health status indices. Also, the high prevalence of multi-drug resistant strains of bacteria has elevated the threat of untreatable bacterial infections and adds urgency to the hunt for new healing strategies (Isaka et al., 2017).

In addition to this problem, antibiotics are sometimes associated with adverse effects on the host, which include hypersensitivity, depletion of beneficial gut and mucosal microorganism, immune suppression and allergic reactions (Namita \& Mukesh, 2012). Therefore, the search for new drugs from other sources, such as plants, is increasingly becoming necessary.
Date palm is among the primogenital trees cultivated by man.In the folk-lore, date fruits have been attributed to have several medicinal properties when consumed either alone or in combination with other herbs. Although, fruit of the date palm served as the principal food for millions of people around the world for several centuries, studies on the health benefits are insufficient and hardly accepted as a healthy food by the health professionals and the public (Vayalil, 2012). In recent years, an explosion of interest in the many health benefits of dates has led to numerous in vitro and animal studies as well as the identification and quantification of various classes of phytochemicals. On the basis of available information in the literature on the nutritional and phytochemical composition, it is apparent that date fruits are highly nutritious and may have several potential health benefits (Vayalil, 2012).

MATERIALS AND METHODS

Sample Collection

Fresh samples (leaves and fruits) of $P$. dactylifera were obtained from a fully grown date tree in a garden beside Federal University Dutse permanent campus and taken to the microbiology laboratory for analysis. 
The fresh samples were washed individually under running tap water to remove soil particles and other dirt. Samples were air dried in the laboratory at room temperature $\left(28^{\circ} \mathrm{C}\right)$ for 15 days, crushed using mortar and pestle, reduced to powder using warring laboratory blender for 5 minutes at high speed and then stored in airtight closed bottles before analysis. Extraction

Extraction was carried out using the Soxhlet apparatus as described by Horowitz (1984), where $25 \mathrm{~g}$ of each (leaf and fruit) powder was extracted in $250 \mathrm{ml}$ of methanol. The powdered plant material was loaded into the Soxhlet extractor. The setup was allowed to run for six (6) hours. The round bottom flask was removed and attached to a rotary evaporator to recover the ethanol and crude extract separately. The crude extract was then transferred into an evaporating dish and placed in a water bath for the excess methanol to escape. The extract was stored in a screwcap bottle at $4^{\circ} \mathrm{C}$ until needed.

Phytochemical Analysis

Phytochemical constituents of the crude extracts of the leaves and fruits were determined using methods described by Sofowora (1993).

Collection, Characterization

and

Identification of Isolates.

All test organism s(pathogenic strains of $E$. coli, K. pneumoniae, S. typhi and P. mirabilis) were collected from the Microbiology unit of Aminu Kano teaching hospital and identified based on the colony morphology, Gram's stain reaction and biochemical tests described below.

Escherichia coli

The isolate was cultured on Eosine Metheylene blue agar for 24-48hrs. Colonies with green metallic sheen were observed which indicates a positive result for $E$. coli, the colonies were subjected to IMViC test where $E$. coli was indole and methyl red positive, VogesProskauer and citrate negative.

Salmonella typhi

The isolate was identified by culturing on Mac ConkeyAgar. Colorless colonies which represents non lactose fermenting organisms were observed and subcultured on Deoxycolate Citrate Agar (DCA).Colorless colonies with a black spot were observed which indicate hydrogen sulfide production by salmonella. It was further cultured on Simon's citrate agar slant for $24 \mathrm{hrs}$. A deep blue or royal blue coloration indicated a positive result. Finally, the

organisms were further subjected to Tripple sugar ion (TSI) test to differentiate S. typhi from S. typhimurium.

\section{Klebsiella pneumoniae}

The isolate was cultured on MacConkey Agar, where it ferments lactose to lactate and yielded a positive result on Voges-Proskauer and negative on Methyl red test.

\section{Proteus mirabilis}

The isolate was cultured on Mac Conkey Agar, colorless flat colonies were observed and yielded a positive result on methyl red and Voges-Proskauer negative.

Preparation of Stock Solution

Stock solution was prepared by mixing $1 \mathrm{~g}$ of each extract in $10 \mathrm{ml}$ of distilled water $(100 \mathrm{mg} / \mathrm{ml})$. Then the concentrations $(40 \mathrm{mg} / \mathrm{ml}, 30 \mathrm{mg} / \mathrm{ml}, 20 \mathrm{mg} / \mathrm{ml}$ and $10 \mathrm{mg} / \mathrm{ml})$ were prepared using the standard dilution formula $\left(C_{1} V_{1}=C_{2} V_{2}\right)$.

Standardization of Inoculum

A suspension of the test bacteria was made by emulsifying loop full of colony into a test tube containing normal saline. Inoculum density of the bacterial suspension was adjusted to that of 0.5 McFarland standard.

Bioassay Procedure

Nutrient agar was prepared according to manufacturer's instructions. After sterilization, the media was allowed to cool at 40 to $45^{\circ} \mathrm{C}$ and poured into petri plates. The plates were labeled with culture name and extract to be used. A sterile cotton-wool swab was dipped into the standardized bacterial suspension and used to seed the entire surface of the agar medium. Using a sterile Cork borer, wells were punched at the center of the agar medium, which were filled with the prepared suspension of extract and incubated (without inverting) at $37^{\circ} \mathrm{C}$ for 24 hours. The zone of inhibition was measured using a ruler to the nearest millimeter.

Determination of Minimum Inhibitory Concentration(MIC)

Plates that showed reasonable zones of inhibition were subjected to MIC determination. Two fold tube dilution was used consisting of five tubes with concentrations of $40 \mathrm{mg} / \mathrm{ml}, 20 \mathrm{mg} / \mathrm{ml}, 10 \mathrm{mg} / \mathrm{ml}, 5 \mathrm{mg} / \mathrm{ml}$ and $2.5 \mathrm{mg} / \mathrm{ml}$. The tube that had the least concentration with no visible signs of growth was recorded as the MIC.

\section{Determination of Minimum Bactericidal Concentration(MBC)}

Plates containing fresh solidified nutrient agar were seeded with inoculum from tubes with no turbidity in the MIC setup and incubated at $37^{\circ} \mathrm{C}$ for $24 \mathrm{hrs}$. The plate with the least concentration of the extract from MIC that showed no growth was recorded as the MBC. 
RESULTS AND DISCUSSION

Phytochemical screening of both the fruit and leaf extracts showed the presence of alkaloids, phenols, steroids and tannins. In addition, Saponins and flavonoids were also detected in the fruit extract (Table 1). The fruit extract of $P$. dactylifera had greater activity on the test organisms than the leaf extract (Table 2) which was in line with the findings of (Aldaihan and Bhat, 2012). Phytochemical screening of both the fruit and leaf extracts showed the presence of alkaloids, phenols, steroids and tannins. In addition, Saponins and flavonoids were also detected in the fruit extract which might be the reason for greater antibacterial activity observed with the fruit extract because Saponins have been reported by Mujahid et al., (2017) as compounds that have the ability to form pores in membranes hence exerting a bactericidal effect. However, MIC and MBC analysis, showed that both extracts were effective against all the test organisms where even low concentrations $(10 \mathrm{mg} / \mathrm{ml}$ and $5 \mathrm{mg} / \mathrm{ml})$ yielded good results (Table 3 and 4). An interesting finding of this research was the susceptibility of Salmonella typhi to the fruit extract of $P$. dactylifera where it was inhibited with a zone of inhibition measuring $38 \mathrm{~mm}, 28 \mathrm{~mm}, 22 \mathrm{~mm}$ and $10 \mathrm{~mm}$ at different concentrations (Table 2). On the contrary, K. pneumonia was inhibited most by the leaf extract with zones of inhibition measuring $34 \mathrm{~mm}, 28 \mathrm{~mm}, 26 \mathrm{~mm}$ and $22 \mathrm{~mm}$ at different concentrations. Infections by Salmonella typhi and $K$. pneumoniae pose a major public health challenge in Nigeria. With the findings of this research $P$. dactylifera might be considered as a potential source of new antibacterial drugs. However, both extracts were less effective than the standard antibiotic ciprofloxacin (Table 2).

Table 1: Phytochemical composition of the leaves and fruit of $P$. dactylifera

\begin{tabular}{lll}
\hline Test & Leaf & Fruit \\
\hline Alkaloids & + & + \\
Flavonoids & - & + \\
Saponins & - & + \\
Tannins & + & + \\
Phenols & + & + \\
Steroids & + & +
\end{tabular}

Key: + = Detected, - = Not detected

Table 2: Antibacterial properties of Methanolic Extract of P.dactylifera on some selected organisms

\begin{tabular}{|c|c|c|c|c|c|c|c|c|c|c|c|c|c|c|c|c|}
\hline \multirow[t]{2}{*}{ Plant extracts } & \multicolumn{16}{|c|}{ Zone of inhibition $(\mathrm{mm})$} \\
\hline & \multicolumn{4}{|c|}{ S. typhi } & \multicolumn{3}{|c|}{ P. mirabilis } & & & \multicolumn{4}{|c|}{ E. coli } & \multicolumn{3}{|c|}{$\begin{array}{l}\text { K. } \\
\text { pneumoniae }\end{array}$} \\
\hline $\begin{array}{l}\text { Concentrations } \\
(\mathrm{mg} / \mathrm{ml})\end{array}$ & A & $\mathrm{B}$ & $\mathrm{C}$ & $\mathrm{D}$ & $A$ & B & $\mathrm{C}$ & $D$ & $\mathrm{~A}$ & $B$ & $\mathrm{C}$ & $\mathrm{D}$ & A & $B$ & $\mathrm{C}$ & $\mathrm{D}$ \\
\hline $\begin{array}{l}\text { Leaf } \\
\text { Fruit } \\
\text { Ciprofloxacin }\end{array}$ & $\begin{array}{l}20 \\
38 \\
56\end{array}$ & $\begin{array}{l}14 \\
28\end{array}$ & $\begin{array}{l}0 \\
22\end{array}$ & $\begin{array}{l}0 \\
10\end{array}$ & $\begin{array}{l}0 \\
24 \\
54\end{array}$ & $\begin{array}{l}0 \\
18\end{array}$ & $\begin{array}{l}0 \\
0\end{array}$ & $\begin{array}{l}0 \\
0\end{array}$ & $\begin{array}{l}0 \\
18 \\
56\end{array}$ & $\begin{array}{l}0 \\
12\end{array}$ & $\begin{array}{l}0 \\
0\end{array}$ & $\begin{array}{l}0 \\
0\end{array}$ & $\begin{array}{l}34 \\
26 \\
52\end{array}$ & $\begin{array}{l}28 \\
20\end{array}$ & & $\begin{array}{l}22 \\
0\end{array}$ \\
\hline
\end{tabular}

Key: $\mathrm{A}=40(\mathrm{mg} / \mathrm{ml}), \mathrm{B}=30(\mathrm{mg} / \mathrm{ml}), \mathrm{C}=20(\mathrm{mg} / \mathrm{ml}), \mathrm{D}=10(\mathrm{mg} / \mathrm{ml})$.

Table 3: Minimum inhibitory concentration (MIC) of Methanolic extract of $P$. dactylifera and ciprofloxacin at different concentration on tested organisms.

\begin{tabular}{lccccccc}
\hline Test organisms & \multicolumn{6}{c}{ Concentration of extracts $(\mathrm{mg} / \mathrm{ml})$} \\
\cline { 2 - 7 } & 20 & 10 & 5 & 2.5 & 1.25 & Ciprofloxacin $(5 \mathrm{mg} / \mathrm{ml})$ \\
\hline S. typhi (Leaf) & - & MIC & + & ++ & +++ & - \\
K. pneumoniae (Leaf) & - & - & - & MIC & + & - \\
E. coli (Fruit) & - & MIC & + & ++ & +++ & - \\
K. pneumoniae (Fruit) & - & - & MIC & ++ & +++ & - \\
S. typhi (Fruit) & - & - & - & MIC & + & - \\
P. mirabilis (Fruit) & - & - & MIC & + & ++ & - \\
\hline Key: & + & + & + & + \\
\hline
\end{tabular}

Key: $+=$ presence of growth, $-=$ no growth, MIC $=$ minimum inhibitory concentration . 
Table 4: Minimum bactericidal concentration (MBC) of Methanolic extract of $P$. dactylifera at different concentration on tested organisms.

\begin{tabular}{lcccc}
\hline Test organisms & \multicolumn{4}{c}{ Concentration of extracts (mg/ml) } \\
\cline { 2 - 5 } & 20 & 10 & 5 & 2.5 \\
\hline S. typhi (Leaf) & - & $\mathrm{MBC}$ & + & ++ \\
K. pneumoniae (Leaf) & - & - & $\mathrm{MBC}$ & + \\
E. coli (Fruit) & $\mathrm{MBC}$ & + & ++ & ++ \\
K. pneumoniae (Fruit) & - & - & $\mathrm{MBC}$ & + \\
S. typhi (Fruit) & - & - & $\mathrm{MBC}$ & + \\
P. mirabilis (Fruit) & - & $\mathrm{MBC}$ & + & ++ \\
\hline
\end{tabular}

Key: + = presence of growth, - = no growth, MIC =minimum bactericidal concentration.

\section{CONCLUSION}

Phoenix dactylifera can be used to reduce the high incidence of some enterobacterial infections especially in northern Nigeria.

\section{Recommendation}

The ability of this plant extracts to inhibit the test organisms indicate the presence of

\section{REFERENCES}

Al-daihan, S. and Bhat, R. S. (2016). Antibacterial activities of extracts of leaf, fruit, seed and bark of Phoenix dactylifera. African Journal of Biotechnology, 11(42): 10021-10025. http://doi.org/10.4314/ajb.v11i42.

Cowan, M. M. (1999). Plant products as antimicrobial agents. Clinical Microbiology Reviews, 12(4): 564-582. http://doi.org/0893-8512/99/04.000.

Horowitz, W. (1984). Methods of analysis of the Association of Official Analytical Chemist, Washington D.C.

Isaka, I., Ahmad, M. G., Ya'u, H. M., \&Amoo, F. K. (2017). Phytochemical Analysis and Antimicrobial Activity of Neocarya macrophylla Leaves Extract. LIFE: International Journal of Health and Life-Sciences, 3(1): 18 34.http://doi.org/dx.doi.org/10.20319 /lijhls.2017.31.1834. biological entities capable of suppressing their growth. Therefore, further phytochemical analysis is recommended to assess the presence of other bioactive compounds that might be of chemotherapeutic importance. Also, GC-MS analysis is recommended to quantify the phytochemicals and to reveal their chemical structures.

Mujahid, N. S., Kutama, A. S., Sani, N. M., and Bashir A. (2017). In-vitro Antifungal Evaluation of Cinnamomum zeylanicum and Leptadenia hastata on Malassezia species. Umyu journal of microbiology research,2(1), 251-256.

Namita, P., \&Mukesh, R. (2012). Medicinal Plants Used As Antimicrobial Agents : A Review. International Research Journal of Pharmacy, 3(1), 31-40.

Sofowora, A. (1993).Screening Plants for Bioactive Agents. In: Medicinal Plants and Traditional Medicinal in Africa. 2nd Ed. Spectrum Books Ltd, Sunshine House, Ibadan, Nigeria, pp. 134-156.

Vayalil, P. K. (2012). Date fruits (Phoenix dactylifera Linn): an emerging medicinal food. Crit Rev Food Sci. Nutr, 52(3),

249-271. http://doi.org/10.1080/10408398.2010 .499824 . 